\title{
Isolation and molecular characterization of Rhizoctonia-like fungi associated with orchid roots in the Quadrilátero Ferrífero and Zona da Mata regions of the state of Minas Gerais, Brazil
}

Ricardo Eustáquio Nogueira ${ }^{1,5}$, Cassio van den Berg ${ }^{2}$, Olinto Liparini Pereira ${ }^{3}$ and Maria Catarina Megumi Kasuya ${ }^{4}$

Received: 20 August, 2013. Accepted: 5 November, 2013

\begin{abstract}
Mycorrhizal associations can be considered required for orchids, which depend on the fungi for germination and establishment in natural conditions. Knowledge of the mycorrhizal fungi is important for programs aimed at the reintroduction, conservation and management of orchid species. The objective of this study was the molecular characterization of Rhizoctonia-like fungi from orchids in the Quadrilátero Ferrifero ("Iron Quadrangle") and Zona da Mata ("Forest Zone") regions of the state of Minas Gerais, Brazil. The affinities of these fungi were studied by comparing the rRNA internal transcribed spacer region with that of other isolates and sequences in GenBank. Three isolates had an affinity for Epulorhiza repens, and one was the holotype of E. epiphytica.
\end{abstract}

Key words: Epulorhiza repens, E. epiphytica, ITS, Tulasnella calospora, Orchidaceae, mycorrhiza

Orchidaceae, one of the largest families of angiosperms, presents significant morphological and reproductive diversity. Production of small seeds that, as a general rule, are associated with symbiotic mycorrhizal fungi is a character seen in all members of the family (Rasmussen 1995). Another unique feature is the protocorm, a parenchymatous structure that develops from the embryo and subsequently becomes the seedling, later differentiating into the apical meristem and roots. Fungi associated with orchids are capable of degrading complex carbohydrates, thus providing the heterotrophic protocorms with simple sugars that are used in their growth and differentiation (Peterson et al. 1998).

Many fungi that have been isolated from orchid roots have been identified as Rhizoctonia-like (Leake 1994). Members of that group do not form asexual spores and all share certain distinctive vegetative characters. Moore (1987) proposed the division of the Rhizoctonia-like fungi into Epulorhiza, Ceratorhiza, and Moniliopsis based on the number of nuclei per hyphal segment and the ultrastructure of the hyphal septum.

Six Epulorhiza species have been described based on the shape and the dimensions of monilioid cells: E. repens (Moore 1987); E. albertensis (Currah et al. 1989); E. anaticula (Currah et al. 1989); E. calendulina (Zelmer \& Currah 1995); E. inquilina (Currah et al. 1997); and E. epiphytica (Pereira et al. 2003). In addition, six Tulasnella species with Rhizoctonia-like anamorphs have been described as orchid mycorrhiza (Warcup \& Talbot 1971): Tulasnella allantospora; $T$. asymmetrica; $T$. calospora $($ anamorph $=$ E. repens $)$; T. cruciata; T. irregularis; and T. violea.

In the present study we isolated Rhizoctonia-like fungi from the roots of adult orchids, sequenced the internal transcribed spacer (ITS) region of the rRNA and compared these sequences with other sequences found in the database of the National Center for Biotechnology Infor-

\footnotetext{
${ }^{1}$ Federal University of Ouro Preto, Institute of Exact and Biological Sciences, Department of Biological Sciences, Laboratory of Microorganism Biology and Technology, Ouro Preto, MG, Brazil

${ }^{2}$ Feira de Santana State University, Department of Biological Sciences, Feira de Santana, BA, Brazil

${ }^{3}$ Federal University of Viçosa, Centre for Agricultural Sciences, Department of Plant Pathology. Laboratory of Seed and Post-Harvest Pathology, Viçosa, MG, Brazil

${ }^{4}$ Federal University of Viçosa, Centre of Biological Sciences and Health, Department of Microbiology, Viçosa, MG, Brazil

${ }^{5}$ Author for correspondence: ricardo_nogueira@oi.com.br
} 
mation (GenBank). We collected two rupicolous species of orchids from rocky fields in the municipalities of Nova Lima (Epidendrum secundum Jacq.; fungal isolate OM16) and Ouro Preto (Acianthera limae (Porto \& Brade) Pridgeon \& M.W. Chase; fungal isolates OM23 and OM24), as well as one epiphytic species in the municipality of São Miguel do Anta (Polystachya concreta (Jacq.) Garay \& H.R. Sweet; fungal isolate OM6), all within the state of Minas Gerais, Brazil. Isolation, as well as morphological and biochemical characterization, followed Nogueira et al. (2005).

We extracted DNA according to Specht et al. (1982). The ITS region (ITS1, 5.8S rRNA and ITS2) was amplified through polymerase chain reaction (PCR) with the primers ITS- 1 and ITS- 4 (TCCGTAGGTGAACCTGCGG and TCCTCCGCTTATTGATGC, White et al. 1990) After purification with ExoSap (GE Healthcare, Piscataway, NJ, USA), we sequenced the DNA fragments bidirectionally, with BigDye Terminator Kit v3.1 (Applied Biosystems, Foster City, CA, USA) and a SpectruMedix SCE2410 sequencer (SpectruMedix LLC, State College, PA, USA), using the same primers employed in the PCR. The sequences were edited and superimposed with the program STADEN 1.6 (Staden et al. 1998) and then compared with accessions in GenBank using the Basic Local Alignment Search Tool. The six sequences with the highest similarities were selected for phylogenetic analysis. Three sequences belonging to the Cantharellales, namely Cantharellus sp. (GenBank accession no. FR852285), Botryobasidium botryosum (GenBank accession no. DQ267124) and Craterellus tubaeformis (GenBank accession no. HM468494), were selected as outgroups. We detected ITS1, 5.8S and ITS2 using the software ITS $x$ (Bengtsson-Palme et al. 2013). We then excluded ITS1 and ITS2 from the outgroups, because the level of divergence rendered them indistinguishable from Epulorhiza. We constructed a matrix by automatic alignment with MUSCLE (Edgar, 2004) followed by manual adjustments. Analyses of maximum parsimony were run using PAUP 4.0 (Swofford, 1998) and Mr Bayes 3.2.1 (Ronquist et al. 2012). For Bayesian analyses, separate models of evolution were selected for ITS1, 5.8S and ITS2 with MRMODELTEST 2.3 (Nylander 2008).

In culture, the isolates showed similar characters, such as the sparse, white aerial mycelium, the submerged colony margin, the lack of polyphenol oxidase production and the binucleate vegetative hyphae with diameter $<4.0 \mu \mathrm{m}$. Those characters allowed us, using the Currah \& Zelmer (1992) key, to identify them as belonging to the genus Epulorhiza.

Because maximum parsimony and Bayesian analyses presented similar topology in the resolved part of the tree, we present in Fig. 1 the Bayesian analyses consensus in which we added the maximum parsimony bootstrap support. The fungal isolates obtained in the present study belong to two distinct lineages. The OM23, OM24 and OM16 isolates group with high support to Epulorhiza repens $($ teleomorph $=$ Tulasnella calospora $)$. However, the
OM6 isolate belongs to a different lineage. In fact it corresponds to the holotype of E. epiphytica (holotype: colony desiccated in cornmeal agar, isolated from $P$. concreta collected in São Miguel do Anta, Minas Gerais, Brazil, November 15, 1999 and deposited in the Federal University of Viçosa Herbarium (code, VIC; voucher 22190). This confirms the differences of this species in relation to E. repens. In addition, OM6 clustered with the sequence from Epulorhiza sp. AJ313438. The latter was identified as E. epiphytica upon clustering with 10 different accessions of this species extracted from Encyclia ghillanyi Pabst (Almeida 2009). The results obtained by Almeida (2009) also show that accession AJ313443, isolated in Asia from the Vanda Miss Joaquim hybrid, and accession EF127682, isolated from Cymbidium goeringii in China, are also closely related to this group. Although E. epiphytica was only recently described as an isolate from Brazilian

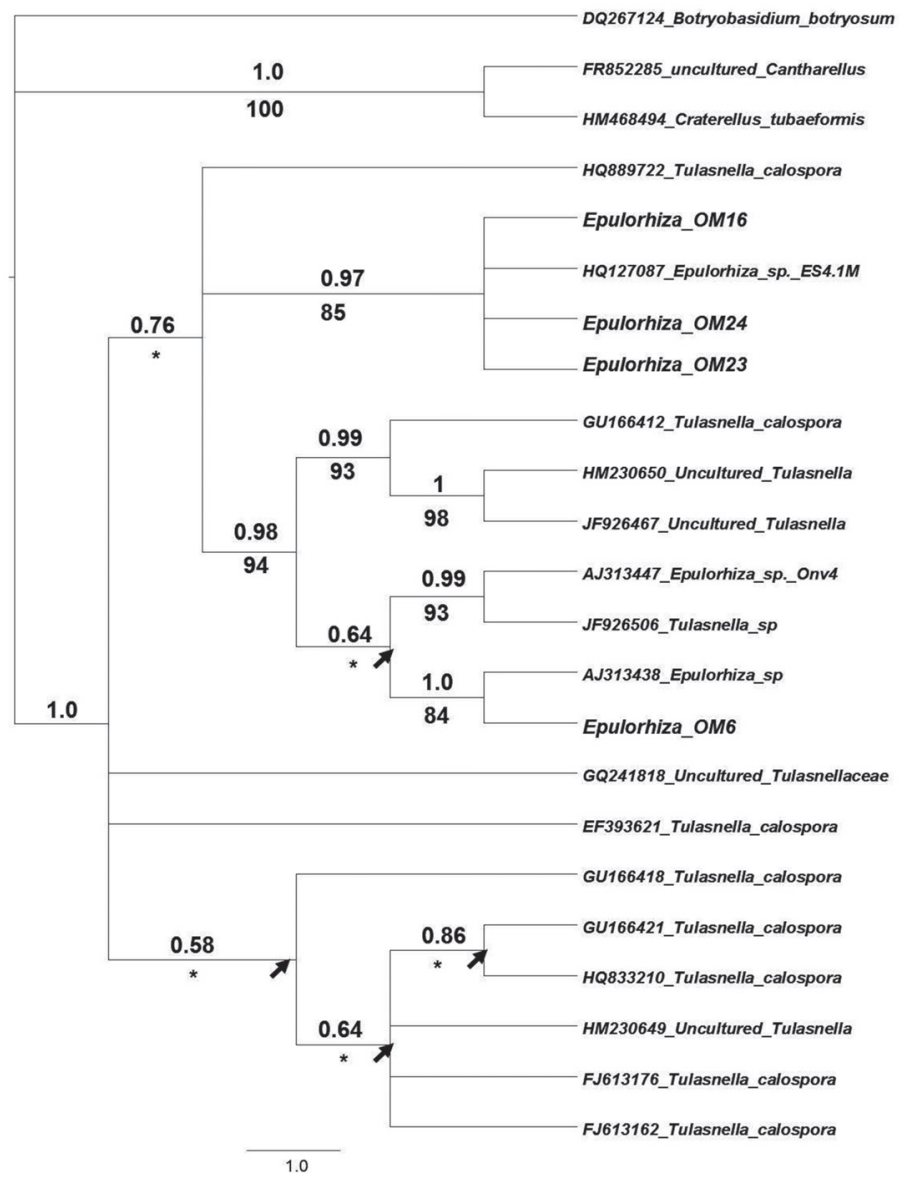

Figure 1. Bayesian consensus of 5000 trees after a Bayesian analysis with 6 million generations, sampling one tree in every 1000 and discarding the first 1000 as burning. Values above the branches correspond to posterior probabilities obtained from this tree set. Values below the branches correspond to bootstrap support values from a maximum parsimony analysis with 1000 bootstrap pseudoreplicates, simple addition, and tree-bisection-reconnection algorithm, limited to $\leq 10$ trees per replication. Arrows indicate branches that collapse in the parsimony strict consensus.

${ }^{\star}$ Bootstrap support $<50 \%$. 
plants, this result indicates that the species is associated with a much larger number of orchids worldwide, which is similar to the case of E. repens. Within the clade in which the OM6 isolate clusters, there is an accession identified as Tulasnella calospora, although the latter was most likely identified erroneously in GenBank or is an artifact due to the limited number of sequences included in the matrix. Almeida (2009) showed that Epulorhiza sp. AJ313438 is associated with another sequence of E. epiphytica (OM6), which is, obviously, another sequence of its holotype.

Epulorhiza repens has been identified by the characteristics of its colonies and hyphae, as described by Moore (1987), and Zelmer \& Currah (1997). Tulasnella deliquescens (syn. T. calospora), the teleomorph of E. repens, has been reported in a wide variety of hosts (Leake 1994). Epulorhiza repens was isolated from adult plants of Spiranthes sinensis (Hadley 1982 ) and Spiranthes lacera (Zelmer \& Currah 1997). More recently, molecular tools for identifying fungi isolated from the Orchidaceae protocorm and adult plants have confirmed the wide distribution of E. repens in Asia (Yuan et al. 2010), Europe (Girlanda et al. 2011) and South America (Pereira et al. 2011). To date, E. epiphytica has been reported only in Brazil, although data from Almeida (2009) indicate that accessions from Ecuador also belong to this species.

The wide distribution and large number of hosts of Epulorhiza repens indicates that the patterns of specificity for the mycorrhizal relationships of this species occur at the population level. Therefore, in addition to molecular characterization using markers similar to those employed in the present study, future studies should be aimed at defining detailed patterns of specificity, which will require tools that address the allelic diversity in the population, such as the use of microsatellites as markers of that diversity.

\section{References}

Almeida, P.R.M. 2009. Associação micorrízica e estudo da variabilidade intra e interespecífica em populações de Encyclia dichroma (Lindl.) Schltr. e Encyclia ghillanyi Pabst (Orchidaceae). Dissertação de Mestrado, Universidade Estadual de Feira de Santana.

Bengtsson-Palme, J.; Ryberg, M.; Hartmann, M.; Branco, S.; Wang, Z.; Godhe, A.; De Wit, P.; Sánchez-García, M.; Ebersberger, I.; de Sousa, F.; Amend, A.S.; Jumpponen, A.; Unterseher, M.; Kristiansson, E.; Abarenkov, K.; Bertrand, Y.J.K.; Sanli, K.; Eriksson, K.M.; Vik, U.; Veldre, V. \& Nilsson, R.H. 2013. Improved software detection and extraction of ITS1 and ITS2 from ribosomal ITS sequences of fungi and other eukaryotes for analysis of environmental sequencing data. Methods in Ecology and Evolution 4(10): 914-919.

Currah, R.S.; Smereciu, E. A. \& Hambleton, S. 1989. Mycorrhizae and mycorrhizal fungi of boreal species of Plantanthera and Coeloglossum (Orchidaceae). Canadian Journal of Botany 68: 1171-1181.

Currah, R.S. \& Zelmer, C.D. 1992. A key and notes for the genera of fungi mycorrhizal with orchids and a new species in the genus Epulorhiza. Reports of the Tottori Mycological Institute 30: 43-59.
Currah, R.S.; Zettler, L.W. \& McInnis, T.M. 1997. Epulorhiza inquilina sp. nov. from Platanthera (Orchidaceae) and a Key to Epulorhiza species. Mycotaxon 61: 338-342.

Edgar, R.C. 2004. MUSCLE: a multiple sequence alignment method with reduced time and space complexity. BMC Bioinformatics 5: 113.

Girlanda, M.; Segreto, R.; Cafasso, D.; Liebel, H.T.; Rodda, M.; Ercole, E.; Cozzolino, S.; Gebauer, G. \& Perotto, S. 2011. Photosynthetic Mediterranean meadow orchids feature partial mycoheterotrophy and specific mycorrhizal associations. American Journal of Botany 98(7): 1148-1163.

Hadley, G. 1982. Orchid mycorrhiza. Pp. 82-118. In: Arditti, J. (Ed.). Orchid biology reviews and perspectives. vol. II. . Ithaca, NY, Cornell University Press.

Leake, J.R. 1994. The biology of myco-heterotrophic ('saprophytic') plants. New Phytologist 127: 171-216.

Moore, R.T. 1987. The genera of Rhizoctonia-like fungi: Ascorhizoctonia, Ceratorhiza gen. nov., Epulorhiza gen. nov., Moniliopsis and Rhizoctonia. Mycotaxon 29: 91-99.

Nylander, J.A.A. 2008. MrModeltest v2.3. Evolutionary Biology Centre, Uppsala University.

Nogueira, R.E.; Pereira, O.L.; Kasuya, M.C.M.; Lanna, M.C.S. \& Mendonça, M.P. 2005. Fungos micorrízicos associados a orquídeas em campos rupestres na região do Quadrilátero Ferrífero, MG, Brasil. Acta Botanica Brasilica 19(3): 417-424.

Pereira, M.C.; Vieira, N.M.; Totola, M.R. \& Kasuya, M.C.M. 2011. Application of total fatty acids composition in characterization and identification of mycorrhizal fungi Epulorhiza spp. of two Epidendrum Brazilian orchids. Revista Brasileira de Ciência do Solo 35(4): 1159-1166.

Pereira, O.L.; Rollemberg, C.L.; Borges, A.C.; Matsuoka, K. \& Kasuya, M.C.M. 2003. Epulorhiza epiphytica sp. nov. isolated from mycorrhizal roots of epiphytic orchids in Brazil. Mycoscience 44: 153-155.

Peterson, R.L.; Uetake, Y. \& Zelmer, C. 1998. Fungal symbioses with orchid protocorms. Symbiosis 25: 29-55.

Rasmussen, H.N. 1995. Terrestrial Orchids: From Seed to Mycotrophic Plant. Cambridge, Cambridge University Press.

Ronquist, F.; Teslenko, M.; van der Mark, P.; Ayres, D.L.; Darling, A.; Höhna, S.; Larget, B. 2012. MrBayes 3.2: efficient Bayesian phylogenetic inference and model choice across a large model space. Systematic Biology 61: 539-542.

Specht C.A.; Dirusso C.C.; Novotny C.P. \& Ullrich R.C. 1982. A method for extracting high-molecular-weight deoxyribonucleic acid from fungi. Analytical Biochemistry 119: 158-163.

Staden, R.; Beal, K.F. \& Bonfield, J.D. 1998. The Staden Package, 1998. Pp. 115-130. In: Misener, S. \& Krawetz, S.A. (Eds.). Computer Methods in Molecular Biology, vol. 132. Totowa, N.J., The Humana Press Inc.

Swofford, D.L. 1998. PAUP* - Phylogenetic Analysis Using Parsimony ( ${ }^{*}$ and other methods) version 4.0. Sunderland, Sinauer Associates.

Warcup, J.H. \& Talbot, P.H.B. 1971. Perfect states of Rhizoctonias associated with orchids II. New Phytologist 70: 35-40.

White, T.J.; Bruns, T.; Lee, S.; Taylor, J. 1990. Amplification and direct sequencing of fungal ribosomal RNA genes for phylogenetics, Pp: 315-322. In: Innis, M.A.; Gelfand, D.H.; Sninsky, J.J.; White, T.J. (Eds.). PCR Protocols a Guide to Methods and Applications. London, Academic Press.

Yuan, L.; Yang, Z.L.; Li, S.Y.; Hu, H. \& Huang, J.L. 2010. Mycorrhizal specificity, preference, and plasticity of six slipper orchids from South Western China. Mycorrhiza 20(8): 559-568.

Zelmer, C.D. \& Currah, R.S. 1995. Ceratorhiza pernacatena and Epulorhiza calendulina spp. nov.: mycorrizal fungi of terrestrial orchids. Canadian Journal of Botany 73: 1981-1985.

Zelmer, C.D. \& Currah, R.S. 1997. Symbiotic germination of Spirantes lacera (Orchidaceae) with a naturally occurring endophyte. Lindleyana 12: 142-148. 